\title{
Model Pengembangan Pedagang Kaki Lima (PKL) Kuliner di Kota Singkawang
}

\author{
Jumhur* \\ Universitas Tanjungpura
}

\begin{abstract}
Even though small businesses are informal, they should always be fostered and facilitated in order to develop these businesses to be more independent in the future. Not to mention, the role of small businesses are very real, especially in employment and to alleviate poverty in Indonesia. There are several important aspects that have not been paid attention for the success of culinary street vendors, for instances organizational, financial, infrastructure, sanitation, environmental and marketing aspects. The main aim of this paper is to examine these aspects that affect the culinary street vendors which is the based on the development model of culinary street vendors that is going to be built in Singkawang city. The methodology used in this paper is descriptive research by combining quantitative and qualitative data analysis. The findings of this study show that street vendors culinary have role in developing local economy and empowering local people because they are able to employ the labors that cannot be employed in the formal sector. The developed models of street vendors culinary that is going to be implemented in Singkawang are dispersed and concentrated models.
\end{abstract}

Keywords: PKL Kuliner, Penataan, Sektor Informal

\section{PENDAHULUAN}

Alternatif usaha bagi tenaga kerja yang tidak terserap dalam usaha sektor formal adalah membuka usaha di sektor informal. Tenaga kerja yang berjumlah $91,86 \%$ ini, yang terserap di sektor formal sebesar 30,51\% dan sisanya sebesar 68,49\% terserap di Usaha Mikro/PKL (Media Indonesia, 16 Mei 2009). Ini membuktikan bahwa alternatif usaha yang ditempuh oleh tenaga kerja yang tidak terserap dalam usaha sektor formal adalah dengan membuka usaha di sektor informal. Kondisi ini tidak jauh berbeda dengan hasil penelitian ILO, di mana $35 \%$ penduduk Indonesia bekerja di sektor formal dan sisanya $65 \%$ bekerja di Usaha Mikro/PKL. Menurut Badan Penanaman Modal Asing, diperkirakan bahwa sekitar 70\% modal domestik dan asing diinvestasikan di kota-kota besar di Indonesia, namun hanya menyerap sekitar 10-16\% tenaga kerja formal.

\footnotetext{
* Korespondensi: Jumhur, Jurusan Ilmu Ekonomi, Fakultas Ekonomi, Universitas Tanjungpura, Jalan Prof. Dr. H. Hadari Nawawi, Pontianak, Indonesia. Alamat Email: jumhurie@ yahoo.com.
} 
Pemberdayaan Usaha Mikro, Kecil dan Menengah (UMKM), termasuk PKL kuliner merupakan langkah strategis dalam meningkatkan dan memperkuat perekonomian dari bagian terbesar rakyat Indonesia. Hal ini sesuai dengan amanat Undangundang Nomor 20 Tahun 2008 tentang Usaha Mikro, Kecil dan Menengah. Karena itu, UMKM diharapkan dapat berperan besar dalam proses demokratisasi, penumbuhan kemandirian masyarakat, peningkatan kesejahteraan dan faktor strategis dalam mengurangi angka pengangguran, penurunan jumlah penduduk miskin, serta mengurangi ketimpangan pendapatan masyarakat.

Peran UMKM dalam perekonomian nasional dapat dilihat dari kedudukannya sebagai pemain utama dalam kegiatan ekonomi di berbagai sektor, penyedia lapangan kerja yang terbesar, pemain penting dalam pengembangan kegiatan ekonomi lokal dan pemberdayaan masyarakat, pencipta pasar baru dan sumber inovasi, dan sumbangannya dalam menjaga neraca pembayaran melalui kegiatan ekspor. PKL sebagai salah satu komponen utama dari Usaha Mikro yang terlibat dalam usaha sektor informal, menghadapi lingkungan yang masih kurang kondusif, sehingga menjadi faktor yang menghambat eksistensi dan perkembangan bisnisnya.

Hal tersebut mengakibatkan kondisi umum PKL di Kota Singkawang mengalami produktivitas dan daya saing yang relatif rendah. Beberapa faktor yang mempengaruhi kinerja PKL yaitu: sulitnya mencari lokasi usaha yang sesuai dengan rencana tata ruang kota dan dukungan pemerintah daerah terhadap penyediaan lokasi usaha PKL masih sangat terbatas. Akibatnya mereka melakukan kegiatan usahanya pada fasilitas-fasilitas umum, seperti badan jalan, trotoar, saluran air, jalur hijau, taman dan sebagainya.

PKL pangan (kuliner) merupakan PKL yang paling sering dan banyak ditemukan di setiap daerah. Kehadiran PKL kuliner telah menjadi bagian dari gaya hidup masyarakat yang membutuhkan pangan yang siap saji. Namun, PKL tersebut umumnya belum menerapkan keamanan pangan dan sanitasi lingkungan yang baik. Hal tersebut secara tidak langsung dapat berpengaruh terhadap kondisi kesehatan masyarakat.

Adapun tujuan penelitian ini yaitu pertama, untuk menganalisis peranan aspek kelembagaan, aspek pembiayaan, aspek sarana dan prasarana, aspek sanitasi dan lingkungan, serta aspek pemasaran yang mempengaruhi keberhasilan PKL Kuliner di Kota Singkawang Kalimantan Barat. Kedua, untuk merancang sebuah model pengembangan PKL kuliner yang dapat diimplementsikan untuk membantu pengembangan PKL kuliner di masa yang akan datang khususnya di Kota Singkawang Kalimantan Barat.

\section{TINJAUAN PUSTAKA}

\subsection{Pengertian Pedagang Kaki Lima}

Istilah sektor informal diperkenalkan oleh Keith Hart pada tahun 1971 dalam penelitiannya tentang "Small-scale Enterpreneurs in Ghana". Hart menggambarkan 
sektor informal sebagai angkatan kerja perkotaan serta berada di luar pasar kerja yang terorganisasi. Sethuraman (1991) menyebutkan "sektor informal sebagai unit-unit berskala kecil yang terlibat dalam produksi dan distribusi barang-barang, dimasuki oleh penduduk kota terutama bertujuan untuk mencari kesempatan kerja dan pendapatan daripada memperoleh keuntungan" (Hazel Moir, 1978). Sampai sekarang baru Sethuraman (1991) dari ILO yang relatif berhasil merumuskan definisi teoritis tentang sektor informal, yang dalam bahasa Indonesia dapat didefinisikan sebagai berikut: "Sektor informal terdiri dari unit-unit usaha berskala kecil yang menghasilkan dan mendistribusikan barang dan jasa dengan tujuan pokok menciptakan kesempatan kerja dan pendapatan bagi diri sendiri dan dalam usahanya itu sangat di hadapkan berbagai kendala seperti faktor modal fisik, faktor pengetahuan dan faktor keterampilan." Kegiatan-kegiatan sektor informal dapat pula dicirikan: mudah masuk, bersandar pada sumberdaya lokal, usaha milik keluarga, operasi skala kecil, padat karya dan adapted technology, keterampilan diperoleh dari luar sistem formal sekolah, tidak diatur dan pasar kompetitif.

Dewasa ini pengertian sektor informal dapat pula dikelompokkan sebagai pengusaha mikro dan kecil sesuai dengan Undang-Undang Nomor 20 Tahun 2008. Dengan kata lain, sektor informal di kota terutama harus dipandang sebagai unit-unit beskala mikro dan kecil yang terlibat dalam produksi dan distribusi barang-barang yang masih dalam suatu proses daripada dianggap sebagai sekelompok perusahaan yang berskala kecil dengan masukan-masukan modal dan pengelolaan yang besar. Pengertian PKL dalam pengaturan ini diartikan secara luas, karena tidak hanya bagian jalan/trotoar, tetapi mencakup pula tempat-tempat untuk kepentingan umum yang bukan diperuntukkan tempat usaha serta tempat lain yang bukan miliknya. PKL adalah orang yang dengan modal yang relatif sedikit berusaha bidang produksi dan penjualan barangbarang (jasa-jasa) untuk memenuhi kebutuhan kelompok tertentu di dalam masyarakat, usaha tersebut dilaksanakan pada tempat-tempat yang dianggap strategis dalam suasana lingkungan yang informal (Haryono, 1989).

Bromley (1979) menyebutkan bahwa PKL adalah suatu pekerjaan yang paling nyata dan paling penting di kebanyakan kota di negara-negara berkembang pada umumnya. PKL pada umumnya adalah self-employed, artinya mayoritas PKL hanya terdiri dari satu tenaga kerja. Modal yang dimiliki relatif tidak terlalu besar, dan terbagi atas modal tetap, berupa peralatan, dan modal kerja. Dana tersebut jarang sekali dipenuhi dari lembaga keuangan resmi, tetapi biasanya berasal dari sumber dana ilegal atau dari supplier yang memasok barang dagangan. Sedangkan sumber dana yang berasal dari tabungan sendiri sangat sedikit. Hal ini berarti hanya sedikit dari mereka yang dapat menyisihkan hasil usahanya, disebabkan rendahnya tingkat keuntungan dan cara pengelolaan uang. Sehingga kemungkinan untuk mengadakan investasi modal maupun ekspansi usaha sangat kecil (Hidayat, 1978). 


\subsection{Studi Pendahuluan yang Telah Dilaksanakan}

Bromley (1979) mengkaji relevansi model dualistik kegiatan ekonomi dan usaha yang diterapkan di negara-negara dunia ketiga. Dalam laporan ILO tentang Kenya, sektor informal dan formal dibedakan sebagai berikut. Kegiatan- kgiatan informal adalah sebuah cara untuk melakukan sesuatu yang dicirikan: mudah masuk, bersandar pada sumber daya lokal, usaha milik keluarga, operasi skala kecil, padat karya dan adapted technology, ketrampilan diperoleh di luar system formal sekolah, tidak diatur dan pasar kompetitif. Moser (1979) menawarkan kerangkateori "petty commodity production" (PCP) dan hubungannya dengan sector kapitalis sebagai alternative dari konsep sector informal (model dualisme ekonomi) yang digunakan oleh programprogram studi World Employment ILO. Kemudian Hart (1991) didasarkan pada hasil penelitian di Ghana. Penulis memaparkan hasil temuannya berdasarkan dua tipologi kesempatan memperoleh penghasilan di kota, yaitu formal dan informal. Formal, melalui gaji dari negara, gaji dari sektor swasta, dan tunjangan-tunjangan pensiun, tunjangan pengangguran. Informal baik yang sah, seperti kegiatan- kgiatan primer dan sekunder, yaitu pertanian, perkebunan yang berorientasi pasar, penjahit, dan sebagainya; usaha tersier dengan modal relatif besar seperti spekulasi barang-barang dagangan, kegiatan sewa-menyewa, dan sebagainya; distribusi kecil- kecilan seperti pedagang pasar, pedagang kelontong, PKL, dan sebagainya; maupun tidak sah seperti jasa (penadah barang curian, pelacuran, mucikari, dan sebagainya) dan transaksi (pencurian dan perjudian).

Tulisan dari Mazumdar (1991) lebih memusatkan perhatian pada implikasi distribusi pendapatan dalam ekonomi kota yang terbagi atas dua macam pasar tenaga kerja, yaitu sektor formal dan sector informal. Sethuraman (1991) menjelaskan bahwa sektor informal dianggap sebagai sebuah manifestasi dari situasi pertumbuhan kesempatan kerja di negara sedang berkembang. Kegiatan memasuki usaha kecil di kota lebih ditujukan untuk mencari kesempatan kerja dan pendapatan daripada memperoleh keuntungan. Mereka yang terlibat sector ini pada umumnya miskin, berpendidikan sangat rendah, tidak terampil, dan kebanyakan adalah para pendatang. Rachbini \& Hamid (1994) mendeskripsikan berbagai hal yang terkait dengan sektor informal perkotaan di Indonesia. Diawali dengan penjelasan mengenai permasalahan dasar ekonomi informal yang bersifat struktural, seperti ketidakseimbangan antara luas tanah dan jumlah penduduk dan buruknya pola kepemilikan tanah, peningkatan jumlah penganggur, menguatnya kekuasaan kaum minoritas termasuk orang asing dalam pedagangan dan investasi, dan adanya dualisme sosial, ekonomi, dan teknologi. Buku ini juga menjelaskan dualism ekonomi yang melihat keterpisahan dari satu system menjadi dua bagian (tradisional-modern, formal-informal), yang berinteraksi secara tidak seimbang.

Firdausy (1995) membahas dua hal. Pertama, model pengembangan sektor informal PKL perkotaan yang diambil dari hasil studi di empat kota (Bandung, Yogyakarta, Semarang, dan Surabaya). Model pengembangan ini berupaya untuk mengoptimalkan potensi sosial-ekonomi sector informal PKL dan mengurangi permasalahan 
yang ditimbulkannya. Kedua, rumusan kebijakan yang harus ditempuh pemerintah agar model pengembangan PKL dapat mencapai tujuan.

Mengacu pada definisi sektor informal yang diterangkan oleh Handayani (2006), berbagai komunitas ini kecuali di fable termasuk dalam sector informal perkotaan. Komunitas yang dibahas dalam penelitian ini lebih beragam dari penelitian Kompip (2004) yang hanya mencakup PKL, becak, dan penata parkir. Dinamika yang dialami oleh komunitas marjinal dalam proses perencanaan dan penganggaran partisipatif cukup baik digambarkan oleh penulis termasuk perbedaan kepentingan antara masyarakat territorial dan sektoral dan keengganan masyarakat territorial untuk melibatkan masyarakat sektoral. Saat ini makin disadari pentingnya peran usaha mikro, termasuk PKL dalam perekonomian Indonesia, terutama peranannya dalam menampung tenaga kerja dan sebagai sumber penghasilan rumah tangga. Kenyataan menunjukkan bahwa usaha mikro mampu menyediakan kesempatan kerja bagi sebagian besar angkatan kerja kita. Bergeraknya para pencari kerja ke sektor informal terkait ketidakmampuan sektor formal dalam menyerap sebagian besar angkatan kerja dan mudahnya memasuki sektor informal. Secara umum untuk dapat memulai usaha di sektor informal tidak diperlukan modal yang besar, tanpa teknologi tinggi, dan tanpa kebutuhan keterampilan khusus.

\section{METODE PENELITIAN}

\subsection{Metode Pengumpulan Data}

Penelitian dilakukan dengan menggunakan data primer dan sekunder. Data primer didapatkan melalui survey terhadap responden yang terdiri dari pimpinan PKL kuliner. Penelitian ini bersifat deskriptif, di mana pendekatan ini digunakan untuk menjelaskan karateristik variabel yang diamati dengan menggunakan frekuensi, rata-rata, nilai maksimum dan minimum serta memberikan interpretasi terhadap hasil tersebut.

Data primer yang berbentuk data kualitatif, dikumpulkan dengan melakukan indepth interview dengan key informan terpilih yaitu ketua PKL kuliner. Pertanyaan yang diajukan berkaitan dengan pandangan informan terhadap peran, kendala dan prospek usaha PKL di masa yang akan datang dalam kaitannya dengan aspek kelembagaan, aspek sanitasi dan lingkungan, aspek pembiayaan dan aspek pemasaran dalam mendukung keberhasilan PKL kuliner di Kota Singkawang. Sedangkan, data sekunder, dikumpulkan dengan berbagai metode dan sumber di antaranya melalui studi pustaka, telaah arsip dan dokumen yang diperoleh dari instansi terkait.

\subsection{Sampel Penelitian}

Pelaku PKL kuliner sebanyak 40 responden di Kota Singkawang dan dinas terkait yakni Dinas Koperasi, Dinas Perdagangan, Dinas Pelayanan KUKM Kota Singkawang serta berbagai sumber lainnya yang ada kaitannya dengan penelitian ini. 


\subsection{Metode Pengumpulan Data}

Data primer diperoleh dari lapangan dengan cara melakukan diskusi terfokus (Focus Group Discussion) dengan melibatkan berbagai pihak (stakeholder), seperti tokoh masyarakat, pelaku bisnis, PKL kuliner, pihak pemerintah, LSM, tokoh adat, akademisi, serta bebagai pihak yang dianggap perlu untuk mendukung keberhasilan peneltian ini.Data sekunder diperoleh dari instansi terkait, seperi Badan Pusat Statistik Kota Singkawang serta berbagai literatur yang berhubungan dengan penelitian ini.

\subsection{Metode Analisis}

Dalam penelitian ini setelah data yang telah dikumpulkan kemudian dilakukan analisa dengan menggunakan metode analisis statistik deskriptif, baik secara kuantitatif maupun kualitatif. Pendekatan ini digunakan untuk menjelaskan karakteristik variabel yang diamati mengunakan frekuensi, rata-rata, serta nilai maksimum dan minimum.

Tabel 1. Lokasi Sebaran PKL di Kota Singkawang

\begin{tabular}{clr}
\hline No & \multicolumn{1}{c}{ Alamat } & Jumlah PKL \\
\hline 1 & Jl. A Yani & 12 \\
2 & Jl. Alayang & 1 \\
3 & Jl. Bawal & 24 \\
4 & Jl. Budi Otomo & 16 \\
5 & Jl. Gm. Situt & 35 \\
6 & Jl. Hasan Saad & 28 \\
7 & Jl. Hulu Stasiun & 10 \\
8 & Jl. Kalimantan & 9 \\
9 & Jl. Kepol Mahmud & 1 \\
10 & Jl. Kurau & 25 \\
11 & Jl. Muslimin Ismail & 7 \\
12 & Jl. Niaga & 9 \\
13 & Jl. Pemuda & 28 \\
14 & Jl. Salam Diman & 9 \\
15 & Jl. Saman Bujang & 2 \\
16 & Jl. Sejahtera & 1 \\
17 & Jl. Setia Budi & 43 \\
18 & Jl. Terminal Pontianak & 1 \\
19 & Jl. Terminal Ptk & 1 \\
20 & Jl. Yohana Godang & 3 \\
21 & Jl. Yos Sudarso & 18 \\
22 & Jl.Bambang Ismoyo & 2 \\
23 & Pasar Hongkong & 30 \\
24 & Sekitar Pekong & 8 \\
25 & Teras Toko & 25 \\
\hline & J U M L A H & $\mathbf{3 5 3}$ \\
\hline
\end{tabular}

Sumber : Dinas Perindustrian dan Pedagangan Kota Singkawang 2013 


\subsection{Lokasi Penelitian}

Penelitian dilaksanakan di Kota Singkawang. Alasan pemilihan kota ini adalah karena kota ini memiliki populasi PKL kuliner cukup banyak dibandingkan kota-kota lainnya yang ada di Kalimantan Barat. Di samping itu, Kota Singkawang penggerak ekonominya yang utama adalah sektor jasa.

\section{TEMUAN DAN PEMBAHASAN}

\subsection{Profil PKL di kota Singkawang}

Profil PKL di kota Singkawang akan dilihat dari beberapa aspek yaitu peta sebaran PKL kota Singkawang, karakteristik PKL Kuliner. Beberapa jenis usaha PKL di Kota Singkawang antara lain: pedagang sembako, pedagang sayuran, peadagang daging, pedagang ikan, pedagang makanan dan minuman, pedagang pakaian, pedagang sepatu, sandal dan tas, pedagang aksesoris, pedagang kerajinan, salon pedagang kelapa, travel, obat-obatan \& jamu, ponsel, kelontong, kaset VCD, buah-buahan.

Berdasarkan hasil observasi, mayoritas PKL kuliner berdagang secara berkelompok, misalnya pada sebagian besar paling banyak terdapat pada Jalan Setia Budi 43 Pedagang, Jl GM. Situt sebanyak 35 pedagang, Pasar Hongkong sebanyak 30 pedagang, Jalan Hasan Saad sebanyak 28 pedagang. Secara lengkap sebaran PKL di Kota Singkawang bisa dilihat pada Tabel 1.

\subsection{Aspek aspek yang mempengaruhi perkembangan PKL Kuliner di Kota Singkawang}

\subsubsection{Aspek Kelembagaan}

Di dalam usahanya membina, menata dan mengembangkan PKL kuliner beberapa dinas atau intitusi lain yang harus terlibat diantaranya adalah biro administrasi perekonomian, biro administrasi sarana dan prasarana kota, Bappeda/Bapeko, dinas perdagangan, dinas perindustrian, dinas pasar, dinas tenaga kerja dan transmigrasi, dinas pendapatan daerah, Satpol PP, dinas tata kota, dinas kebersihan dan pertamanan, dinas pekerjaan umum, dinas perhubungan, dinas kesehatan, Balai POM, organisasi PKL kuliner (asosiasi PKL), koperasi PKL kuliner, lembaga bantuan modal/finansial, dan perguruan tinggi.

Sementara itu keamanan pangan yang dijajakan oleh PKL kuliner sangat memerlukan keterlibatan dinas kesehatan dan Balai Pengawasan Obat dan Makanan (Balai POM). Seluruh dinas/institusi yang terlibat tersebut tentunya bisa bekerja secara efektif jika dapat memanfaatkan fungsi paguyuban atau asosiasi PKL kuliner sebagai wadah para PKL kuliner dalam berinteraksi dengan pemda dan jajarannya. Sementara itu, perguruan tinggi misalnya kegiatan penelitian dan pengabdian kepada masyarakat 
dapat mengambil peran yang sangat penting dalam penataan dan pengembangan PKL kuliner.

Hasil survei lapangan di Kota Singkawang menunjukkan sebagian besar PKL belum mendapatkan pembinaan dari pemda. PKL kuliner tersebut sangat membutuhkan pembinaan dari pemda agar memiliki kinerja yang lebih baik. Proses pembinaan tersebut dapat dijadikan sebagai sarana interaksi antara PKL kuliner dengan pemda. Dalam pengembangannya PKL kuliner yang membentuk koperasi perlu dibina secara kontinu dan intensif, kemudian setelah koperasi dapat mandiri, baru dapat dilakukan pengawasan secara berkala. Proses pembinaan dan penertiban PKL kuliner harus dilakukan dengan menggunakan landasan hukum yang kuat dan jelas.

\subsubsection{Aspek Pembiayaan}

Pada tahap awal usaha PKL kuliner, sumber pembiayaan utamanya berasal dari modal pribadi. Setelah usaha tersebut mulai berjalan baru kemudian muncul pembiayaan dari sumber lain misalnya dalam bentuk dana bergulir dari koperasi simpan pinjam ataupun bantuan fasilitas berdagang (misalnya tenda) dari pihak sponsor. Setelah PKL kuliner tersebut berkembang ke arah sektor formal (tergabung dalam anggota koperasi), kemudian perbankan konvensional mulai tertarik untuk memberikan dukungan pembiayaan.

Koperasi PKL kuliner dapat berperan dalam memberikan bimbingan/pelatihan/ pendampingan kepada PKL kuliner dalam meningkatkan adminstrasi keuangan dan akses PKL terhadap sumber pembiayaan: pemerintah, lembaga keuangan, dan CSR. Deskripsi singkat peran dari pemangku kepentingan dalam penyediaan pembiayaan bagi PKL-kuliner.

Peran PEMDA dalam pengembangan aspek pembiayaan PKL pangan diantaranya: Pihak pemda kabupaten/kota berperan dalam mengalokasikan anggaran yang memadai untuk pembiayaan usaha mikro, mensosilisasikan berbagai skema pembiayaan usaha mikro, membuat mekanisme pengelolaan dana usaha mikro dari pemda, dan memfasilitasi akses PKL kuliner terhadap pemanfaatan dana CSR. Sedangkan perbankan bisa memainkan peran dalam aspek pembiayaan berupa penyaluran dana KUR mikro, membentuk keterkaitan dengan koperasi simpan pinjam dalam pengeloaan dana usaha mikro.

\subsubsection{Aspek Sarana dan Prasarana Usaha}

Sarana dan prasarana usaha yang dimiliki PKL kuliner saat ini di Kota Singkawang umumnya belum terencana dan tertata baik. Akan tetapi, terdapat satu prasyarat agar sarana dan prasarana untuk PKL kuliner dapat disediakan dan ditata dengan baik yaitu bahwa PKL kuliner harus terkumpul dalam satu lokasi. Peran pemerintah daerah dalam pengembangan aspek sarana dan prasarana PKL kuliner di kota Singkawang dapat berupa menentukan dan mengatur lokasi dan atau waktu usaha 
PKL kuliner, menyediakan fasilitas air bersih, listrik, toilet, parkir, dan tempat sampah di lokasi PKL kuliner, memfasilitasi kemitraan PKL kuliner dengan pihak sponsor, serta memfasilitasi pengadaan, pemeliharaan dan penggunaan sarana usaha. Sedangkan Koperasi PKL kuliner berperan dalam pengelolaan dan pemanfaatan sarana dan prasarana yang ada sehingga pemanfaatannya dapat optimal, tertib, dan adil, termasuk didalamnya adalah untuk masalah pemeliharaan yang seringkali terabaikan.

Peran pemda dalam penataan aspek sarana dan prasarana usaha PKL kuliner, antara lain; menyediakan lahan sebagai lokasi usaha yang dapat digunakan oleh PKL kuliner sesuai dengan ketentuan yang berlaku, melakukan penataan dan pengembangan sarana dan prasarana PKL kuliner melalui wadah koperasi PKL kuliner, melakukan sosialisasi/penyuluhan/bimbingan kepada PKL kuliner dalam menggunakan lokasi usaha dengan memberikan peran kepada koperasi dalam pengelolaannya, melakukan fasilitasi untuk memperkuat pengadaan dan pemeliharaan sarana dan prasarana usaha PKL kuliner melalui koperasi dan melakukan mediasi/pendampingan dalam kemitraan dengan pihak ketiga dalam pengadaan/pengelolaan sarana dan prasarana usaha PKL kuliner melalui koperasi dalam bentuk sponsorship, pinjaman lunak atau CSR untuk membangun "pusat makanan/jajanan”. Dalam hal pengembangan sarana dan prasarana, pemda dapat mengeluarkan kebijakan yang ditujukan untuk pengadaan prasarana umum yang dapat mendorong dan mengembangkan pertumbuhan usaha PKL kuliner dan memberikan keringanan tarif prasarana tertentu bagi PKL kuliner.

\subsubsection{Aspek Sanitasi Lingkungan}

Aspek sanitasi lingkungan sering menjadi masalah dalam usaha penataan dan pemberdayaan PKL-kuliner. Hal ini secara umum disebabkan masih rendahnya pengetahuan mereka akan hal ini. Untuk memperbaiki situasi, dapat dilakukan antara lain melalui pelatihan/himbauan, misalnya dalam hal penyediaan dan penggunaan air bersih, pencucian dengan air mengalir, tidak membuang sampah sembarangan, membuang makanan/minuman yang sudah tidak layak konsumsi, tidak menggunakan pengawet/pewarna/kemasan yang tidak diizinkan, melindungi produk jualannya dari kotoran/debu/binatang, dan sebagainya. Peran pemerintah daerah dalam pengembangan aspek sanitasi lingkungan secara singkat dapat dilakukan dengan merencanakan tata ruang kota/daerah, menyediakan fasilitas pendukung sanitasi lingkungan, serta bekerjasama dengan pihak yang berkompeten untuk memberikan pembinaan dan pelatihan pentingnya sanitasi lingkungan. Sedangkan Koperasi PKL Kuliner dapat memainkan peran mengelola pemanfaatan sarana dan sarana sanitasi lingkungan, menjadikan media pembimbingan dan pembinaan sanitasi lingkungan.

Aspek sanitasi lingkungan tidak lepas dari isu keamanan pangan. Dalam hal ini sebaiknya para pihak yang terlibat saling bahu membahu dalam mewujudkan mutu dan keamanan pangan yang baik. PKL kuliner diwajibkan menjual produk pangan yang layak dikonsumsi. Terkait dengan isu keamanan pangan, pemerintah pusat dapat 
menyusun legislasi dan peraturan hukum di bidang pangan, menyediakan sarana dan prasarana pelayanan yang terkait bidang kesehatan dan melakukan investasi dalam ketersediaan infrastruktur dan bahan baku bagi PKL kuliner.

\subsubsection{Pemasaran}

Berdasarkan hasil diskusi (FGD) pemasaran PKL kuliner di kota Singkawang aspek pemasaran sebaiknya dilakukan secara kolektif dalam rangka meningkatkan dampak dan menekan biaya pemasaran. Pemasaran misalnya dapat dilakukan melalui media masa dengan difasilitasi oleh pihak pemda dan koperasi/paguyuban. Kegiatan penataan dan pembinaan sebagai prasyarat promosi akan sangat sulit dilaksanakan tanpa peran aktif koperasi/paguyuban.

Peran dari setiap stakeholder dalam pengembangan aspek pemasaran sebagai berikut. Pemda sangat berkepentingan untuk memasarkan pengelolaan dan penataan PKL-kuliner yang telah mereka lakukan. Lokasi penataan PKL kuliner dapat dipromosikan sebagai daerah wisata kuliner khas dari masing-masing daerah. Sukses program pemasaran akan berdampak kepada peningkatan pendapatan masyarakat, kas daerah, ketertiban, keindahan, dan mendorong PKL kuliner lain agar lebih mudah dibina. Karena itu, dalam pengembangan bidang pemasaran pemda dapat memberikan dukungan penyediaan sarana pemasaran yang meliputi penyelenggaran uji coba pasar, lembaga pemasaran, penyediaan rumah dagang dan promosi usaha PKL kuliner. Selain itu juga, menyediakan tenaga konsultan profesional dalam bidang pemasaran.

Kegiatan promosi yang dilakukan oleh koperasi dan pemda dapat berjalan baik dengan didukung oleh faktor-faktor yang berpengaruh pada kinerja PKL kuliner, yaitu kondisi lokasi usaha, keterjangkauan lokasi usaha dan prospek konsumen. Hasil survei lapang menunjukkan sebagian besar PKL kuliner memiliki kondisi lokasi usaha yang strategis, mudah dijangkau oleh kendaraan umum, dan memiliki prospek konsumen yang ramai. Faktor-faktor tersebut diharapkan dapat memudahkan koperasi dan pemda untuk mempromosikan lokasi PKL kuliner.

\subsection{Model Pengembangan PKL Kuliner Di Kota Singkawang}

Penanganan dan pengembangan PKL khususnya yang bergerak di bidang pangan dapat dilihat dalam perspektif ketahanan pangan nasional. Ketahanan pangan mencakup 4 aspek atau pilar utama yaitu aspek ketersediaan, aspek keterandalan persediaan, aspek asksesibilitas dan aspek konsumsi (Hariyadi, 2007). Tingginya jumlah masyarakat yang mengkonsumsi pangan baik dalam bentuk makanan camilan, makanan utama, maupun minuman yang disediakan oleh PKLKuliner menyebabkan penanganan PKL Kuliner harus dilakukan secara benar dan menyeluruh.

Model yang dikembangkan dalam kajian ini difokuskan untuk pengembangan dan pembinaan PKL yang bergerak di bidang pangan. Karena itu, beberapa aspek sangat 
spesifik dan hanya cocok untuk PKL kuliner. Aktor utama yang berperan dalam pembinaan dan pengembangan PKL kuliner adalah pemerintah daerah (pemda kabupaten dan kota). Hal ini karena banyak aspek penataan dan pengembangan PKL kuliner yang berada di bawah kewenangan pemda kota seperti misalnya terkait registrasi, penyediaan fasilitas bersama, dan tata ruang. Selain itu, karena masih perlunya penjabaran UU No. 20 Tahun 2008 tentang Usaha Mikro. Dalam hal ini, pemda (kabupaten/kota) harus mampu menjadi fasilitator dalam mendorong PKL menjadi sektor usaha formal sehingga PKL dapat meningkatkan kinerjanya dan tidak lagi menimbulkan masalah sosial. Keterlibatan institusi atau pihak lain misalnya Kementerian Negara Koperasi dan UKM adalah sebagai aktor pendukung.

Berdasarkan hasil observasi lapangan dengan dan hasil pembahasan FGD menjadi masukan dalam mendesain model umum penataan PKL. Model umum yang dikem-bangkan dalam penelitian ini yaitu model terkonsentrasi (concentrated) dan model tersebar (dispersed). Dalam model terkonsentrasi, pihak pemda kota Singkawang merencanakan tata ruang kota/daerah dan mendorong PKL agar dapat berkelompok pada suatu daerah tertentu yang menjadi lokasi usaha bersama. Pengembangan PKL dengan model terkonsentrasi memiliki keuntungan yaitu dapat memudahkan dalam penataan kelembagaan PKL. PKL yang telah berkelompok akan mudah dalam membentuk paguyuban dan akhirnya menjadi koperasi. Koperasi PKL yang telah terbentuk dapat berperan sebagai mediator/fasilitator untuk memenuhi kebutuhan PKL dan meningkatkan kinerjanya antara lain dalam hal penyediaan sarana dan prasarana usaha, pembiayaan, sanitasi lingkungan dan pemasaran produk.

Dengan model terkonsentrasi akan memudahkan dalam penyaluran fasilitas bersama antara lain air bersih, listrik, sanitasi, tempat pembuangan sampah, dan akses jalan yang dapat menunjang kinerja PKL, dan selain itu juga dapat memudahkan aspek pemasaran untuk dipromosikan sebagai daerah wisata kuliner khas dari masing-masing daerah melalui media masa dengan difasilitasi oleh pihak pemda dan koperasi/ paguyuban. Di samping memeliki beberapa keunggulan diatas model PKL yang terkonsentrasi ini memiliki juga beberapa kelemahan yaitu harus ada daerah yang dijadikan sebagai tata ruang untuk lokasi usaha bersama PKL, kemudian kelemahan lain dari model ini adalah pemerintah daerah dapat mengalami kesulitan untuk menggiring PKL ke lokasi usaha yang baru karena PKL khawatir akan kehilangan konsumen yang dikhawatirkan akan berdampak terhadap penurunan pendapatan PKL kuliner, dan pindahnya PKL ke tempat usaha yang baru seringkali rawan dengan terjadinya manipulasi dalam proses relokasi oleh pihak-pihak yang mempunyai kepentingan lain.

Dalam kenyataannya di lapangan, PKL kuliner biasanya memenuhi sudut-sudut kota, memenuhi terminal, rumah sakit, pusat-pusat pendidikan dan sebagainya. Pengembangan PKL kuliner dengan model tersebar ini menuntut pemerintah daerah untuk aktif berperan dalam mendata/meregistrasi, mengatur lokasi usaha PKL yang telah ada, dan mengatur waktu kegiatan usaha PKL kuliner sehingga dapat meminimalkan 
dampak negatif keberadaan PKL kuliner. Pengembangan PKL kuliner dengan model tersebar memiliki keuntungan yaitu Pemerintah daerah tidak perlu menyediakan tempat baru untuk relokasi PKL kuliner. Sehingga dalam hal ini akan menguntungkan pemda karena tidak diperlukan investasi dan biaya yang banyak untuk penataan PKL kuliner tidak terlalu besar.

Dalam model tersebar, partisipasi PKL kuliner dalam proses penataan dan pembinaan akan lebih tinggi karena PKL merasa berada dalam habitatnya dan tidak khawatir kehilangan konsumen. Kementerian Negara Koperasi dan UKM berperan sebagai fasilitator PKL kuliner terhadap akses pembiayaan melalui Koperasi Simpan Pinjam dan mendukung pembinaan PKL kuliner dengan program inkubator melalui BDS (Bussiness Development Service), sehingga PKL kuliner tersebut dapat menjadi wirausaha binaan. Namun model ini masih memiliki kelemahan seperti PKL kuliner akan relatif sulit untuk membentuk kelompok dan koperasi, lokasi PKL kuliner yang relatif tersebar dan menyebabkan pengadaan fasilitas bersama untuk menunjang kinerja PKL kuliner menjadi sulit, dan lokasi usaha PKL kuliner yang tidak sesuai/tidak mengikuti tata ruang dapat menimbulkan masalah sosial antara lain mengganggu ketertiban dan kenyamanan. Untuk mengatasi kelemahan ini diperlukan peran aktif dari pemerintah daerah dan institusi lain yang terkait dalam melakukan pembinaan dan pengembangan PKL kuliner. Lebih lanjut pemerintah daerah tingkat II juga berperan dalam pengaturan lokasi usaha, registrasi, pengaturan waktu, dan perkuatan modal PKL kuliner.

Berdasarkan kedua model tersebut (terkonsentrasi dan tersebar) akan dilakukan pengkajian lebih lanjut ke dalam lima aspek yaitu aspek kelembagaan, aspek pembiayaan, aspek sarana dan prasarana usaha, aspek sanitasi lingkungan dan aspek pemasaran. Penentuan model pengembangan PKL kuliner yang paling tepat untuk setiap daerah harus disesuaikan dengan kondisi lokal spesifik yang ada dengan tetap memperhatikan kelima aspek tersebut secara komprehensif.

\section{KESIMPULAN}

Pedagang Kaki Lima (PKL) sebagai salah satu komponen sektor informal berperan dalam mengembangkan ekonomi lokal dan pemberdayaan masyarakat sehingga mampu memperluas lapangan pekerjaan. Melalui Usaha Mikro dan Kecil, PKL terbukti menyerap tenagakerja yang tidak dapat dipekerjakan pada sektor formal seperti di industri. Namun keberadaan PKL juga sering dianggap menimbulkan masalah di perihal ketertiban dan kenyamanan dalam pemukiman. Sebagian besar PKL tersebut ternyata tinggal dan berusaha di pemukiman padat pada wilayah perkotaan.

Dukungan pemda terhadap penyediaan fasilitas dalam pengembangan PKL kuliner berperan untuk menumbuhkan dan meningkatkan kemampuan daya saing PKL 
kuliner. Berdasarkan informasi yang diperoleh, pada umumnya PKL menyatakan belum ada pembinaan yang efektif terhadap kegiatan usaha kaki lima dari pemda. Mereka memandang perlunya pembinaan dari pemerintah daerah agar kinerja PKL kuliner menjadi lebih baik melalui interaksi antara PKL dengan pemerintah. PKL memerlukan akses permodalan dan kredit tanpa agunan, kepastian dan penataan lokasi usaha, pengembangan koperasi PKL, pelatihan teknis, serta registrasi/pencatatan data PKL.

Model pengembangan PKL kuliner di Kota Singkawang untuk pilihan kebijakan yang dirumuskan melalui studi kasus mempunyai dua model yaitu model terkonsentrasi (concentrated) dan model tersebar (dispersed). Pengembangan PKL dengan model terkonsentrasi memiliki keuntungan yaitu dapat memudahkan dalam penataan kelembagaan PKL kuliner. PKL kuliner yang telah berkelompok akan mudah dalam membentuk paguyuban dan akhirnya menjadi koperasi. Koperasi PKL kuliner yang telah terbentuk dapat berperan sebagai mediator/fasilitator untuk memenuhi kebutuhan PKL kuliner dan meningkatkan kinerjanya. Sehingga pengembangan PKL kuliner dengan model tersebar ini maka pemerintah daerah berperan dalam mendata/meregistrasi, mengatur lokasi usaha PKL kuliner yang telah ada, dan mengatur waktu kegiatan usaha PKL kuliner sehingga dapat meminimalkan dampak negatif keberadaan PKL kuliner. Pengembangan PKL kuliner dengan model tersebar memiliki keuntungan yaitu pemerintah daerah tidak perlu menyediakan tempat baru untuk relokasi PKL kuliner.

Kementerian Negara Koperasi dan UKM dapat memprakarsai lokakarya penjabaran UU No. 20/2008 tentang UMKM melalui peraturan pemerintah dan Peraturan/Keputusan Menteri Negara KUKM, khususnya yang terkait dengan PKL. Pemerintah daerah provinsi dan pemerintah kabupaten/kota menerbitkan peraturan tentang pembinaan, penataan dan pengendalian PKL, termasuk PKL kuliner, dengan menyelaraskannya dengan UU Otonomi Daerah serta kegiatan perluasan lapangan kerja dari Depnakertrans. Lokakarya ini diharapkan menghasilkan kebijakan publik yang terpadu dalam persoalan penyediaan pangan sehat bagi masyarakat berpendapatan rendah.

Dalam upaya menajamkan pembinaan PKL kuliner daerah, diperlukan upaya pendataan bagi PKL khususnya PKL kuliner terutama di wilayah perkotaan. Data dasar tersebut kemudian dapat dijadikan rujukan teknis guna penyusunan program perkuatan permodalan, perbaikan kesehatan lingkungan serta penerapan teknologi tepat guna.

Untuk pemerintah kabupaten/kota yang memiliki potensi eksistensi PKL kuliner untuk implementasi model pengembangan PKL berbasis potensi lokal, disarankan untuk melaksanakan diskusi implementasi kebijakan yang melibatkan Kementerian Negara KUKM, perguruan tinggi, Depdagri dan pemerintah daerah, serta LSM setempat. 


\section{DAFTAR PUSTAKA}

Bromley, R. (1979). IntroductionThe Urban Informal Sektor: Why Is It Worth Discussing? The Urban Informal Sektor: Critical Perspectives on Employment and Housing Policies. R. Bromley. Oxford: Pergamon Press, 1031-1032.

Bromley, R. (1979). Organization, Regulation and Exploitation in the SoCalled 'Urban Informal Sektor': The Street Traders of Cali, Colombia. The Urban Informal Sektor: Critical Perspectives on Employment and Housing Policies. R. Bromley. Oxford: Pergamon Press, 1161-1172.

Firdausy, C. M. (1995). Model dan Kebijakan Pengembangan Sektor Informal Pedagang Kaki Lima. Pengembangan Sektor Informal Pedagang Kaki Lima di Perkotaan. C. M. Firdausy. Jakarta: Dewan Riset Nasional dan Bappenas Puslitbang Ekonomi dan Pembangunan LIPI, 139156.

Handayani, S. (2006). Pelibatan Masyarakat Marginal dalam Perencanaan dan Penganggaran Partisipatif: Sebuah Pengalaman di Kota Solo. Solo, KOMPIP dan The Ford Foundation.

Haryono, T. (1989).Faktor-faktor Yng Mempengaruhi Keberhasilan Usaha Pedagang Kaki Lima : Studi Kasus di Kodya Surakarta. Fakultas Pasca Sarjana, Universitas Gajah Mada, Yogjakarta.

Hariyadi, P., Sukarno, Purnomo, E. H., Sumarto, \& Putri, V.B. (2009). Ketahanan Pangan Sebagai Fondasi Ketahanan Nasional. SEAFAST Center IPB.

Hart, K. (1991). Sektor Informal. Urbanisasi, Pengangguran, dan Sektor Informal di Kota. C. Manning and T. N. Effendi. Jakarta: Yayasan Obor Indonesia, 78-89.

Hidayat. (1978). Peranan Sektor Informal Dalam Perekonomian Indonesia dalam Ekonomi Keuangan Indonesia, 26(4).

Sektor Informal: Punya Makna Strategis di Bidang Sosial Ekonomi di Masa Depan, makalah disampaikan dalam "Seminar Nasional tentang Sektor Informal dalam PJP Tahap Kedua". (1993, December 15) diselenggarakan oleh DPP Pemuda Pancasila, bertempat di Gedung Bentara Budaya (Kompas). Jakarta.

Kompip Solo \& Lab. UCYD. FISIP UNS Solo. (2004). Kajian Implikasi Otonomi Daerah dalam Pemberdayaan Masyarakat Marjinal di Kota Surakarta. Solo, Kompip Solo dan the Ford Foundation.

Mazumdar, D. (1991). Sektor Informal di Kota: Analisis Empiris Terhadap Data dari Berbagai Negara di Dunia Ketiga. Urbanisasi, Pengangguran, dan Sektor Informal di Kota. C. Manning and T. N. Effendi. Jakarta: Yayasan Obor Indonesia, 109-137. 
Moser, C. N. (1979). Informal Sektor or Petty Commodity Production: Dualism or Dependence in Urban Development? The Urban Informal Sektor: Critical Perspectives on Employment and Housing Policies. R. Bromley. Oxford: Pergamon Press, 1041-1064.

Moir, Hazel (1978). Jakarta Informal Sektor. LEKNAS-LIPI, Jakarta.

Pena, S. (1999). Informal Markets: Street Vendors in Mexico City. Habitat International, 23 (3), 363-372.

Rachbini, D. J. \&A. Hamid (1994). Ekonomi Informal Perkotaan: Gejala Involusi Gelombang Kedua. Jakarta: LP3ES.

Sethuraman, S. V. (1991). Sektor Informal di Negara Sedang Berkembang. Urbanisasi, Pengangguran, dan Sektor Informal di Kota. C. Manning and T. N. Effendi. Jakarta: Yayasan Obor Indonesia, 90-108.

Pemerintah Provinsi DKI Jakarta. (1978). Peraturan Daerah Provinsi DKI Jakarta Nomor 5 Tahun 1978 tentang Pola Pembinaan dan Penataan Pedagang Kaki Lima di Wilayah Provinsi DKI Jakarta. Jakarta : Biro Pengembangan Produksi Daerah DKI Jakarta.

Purwanugraha, H. A\& T.A.H. Agung M. H. (2002).Dampak Krisis Ekonomi Terhadap Keberadaan Pedagang Kaki Lima di Kawasan Malioboro: Studi Pada Aspek Manajemen dan Pengelolaan Modal. Fakultas Ekonomi, Universitas Atmajaya, Yogyakarta.

Widjajanti, R. (2000). Penataan Fisik Pedagang Kaki Lima pada Kawasan Komersial di Pusat Kota. Studi Kasus : Simpang Lima Semarang, Tesis 40 tidak diterbitkan, Magister Teknik Pembangunan Kota Institut Teknologi Bandung. 